\title{
Studi Manajemen Produksi Batik Tanah Liek Citra di Kabupaten Dharmasraya
}

\author{
Febtia Intan Adyatami \\ Universitas Negeri Padang, Sumatra Barat \\ E-mail: febtiaintanadyatami@gmail.com
}

\begin{abstract}
ABSTRAK
Tujuan penelitian ini adalah untuk mengetahui manajemen produksi Batik Tanah Liek Citra di Kabupaten Dharmasraya. Lokasi penelitian berada di Jorong Teluk Sikai, Nagari, Sungai Duo, Sitiung, Kabupaten Dharmasraya, Sumatra Barat. Penelitian ini mempergunakan pendekatan kualitatif. Pengumpulan data dilakukan dengan melakukan pengamatan dan wawancara. Hasil penelitian menunjukkan bahwa manajemen produksi Batik Tanah Liek Citra yang dilakukan oleh owner menggunakan metode pemberdayaan dalam menentukan perajin atau tenaga kerja yang menjadi sumber daya utama pada produksi kain Batik Tanah Liek Citra melalui fungsi manajemen: perencanaan, pelaksanaan, dan pengawasan. Kesimpulan dari penelitian ini adalah fungsi manajemen pada manajemen produksi industri Batik Tanah Liek Citra mampu melestarikan budaya membatik khas masyarakat Minangkabau di Kabupaten Dharmasraya, Provinsi Sumatra Barat.
\end{abstract}

Kata kunci: manajemen produksi, batik tanah liek citra, kabupaten dharmasraya

\section{Study of Tanah Liek Citra Batik Production Management in Dharmasraya Regency ABSTRACT}

This research aimed to determine the production management of Batik Tanah Liek Citra in Dharmasraya Regency. The research location was in Jorong Teluk Sikai, Nagari, Sungai Duo, Sitiung, Dharmasraya Regency, West Sumatra. This research used a qualitative approach. Data collection was done by observation and interviewed. The results showed that the management of Batik Tanah Liek Citra production carried out by the owner uses the empowerment method in determining the craftsmen or workers who are the primary resources in the production of Batik Tanah Liek Citra through management functions: planning, implementation, and supervision. The conclusion from this research is the management function in the management production of industrial Batik Tanah Liek Citra can preserve the batik culture typical of the Minangkabau community in Dharmasraya Regency, West Sumatra Province.

Keywords: production management, batik tanah liek citra, dharmasraya regency

\section{PENDAHULUAN}

Tradisi membatik yang terdapat di Pulau Sumatra hingga saat ini masih terus dilakukan seperti Batik Jambi dari Jambi, Batik Basurek dari Bengkulu, dan Batik Tanah Liek (tanah liat) dari Sumatra Barat. Batik Tanah Liek merupakan batik yang menjadi ciri khas Minangkabau. Batik Tanah Liek menggunakan pewarna alam dari tanah liat, proses pembuatannya sama dengan batik pada umumnya hanya saja proses pewarnaannya menggunakan tanah liat (Arssad, et al., 2015). Tanah liat atau 
biasanya orang Sumatra Barat menyebutnya Tanah Liek, menurut Ramanto dalam Arssad, et al. (2015) mengatakan bahwa tanah liat adalah salah satu dari jenis tanah hasil dari pelapukan kulit bumi. Jenis tanah ini termasuk klasifikasi Alfisol atau Tanah Besi Aluminium. Tanah ini adalah batuan Feldspar yang mengandung material Alumina (Al203) dan Silica (SiO2), bercampur Potash (K2O) dan Soda (Na2O). Setelah melalui proses pelapukan yang panjang dan berabad-abad maka, bahan Potash dan Soda memisahkan diri dari Feldspar. Setelah itu tinggallah bahan Alumina dan Silica bercampur air dan bahan mineral yang kotor (impurities). Bahan inilah yang dinamakan tanah liat (clay).

Berdasarkan Arssad, et al. (2015), di Sumatra Barat terdapat tiga pusat pembuatan Batik Tanah Liek, yakni di Kabupaten Dharmasraya, Kabupaten Pesisir Selatan, dan Kabupaten Tanah Datar. Di Kabupaten Dharmasraya pusat pembuatan Batik Tanah Liek, yang bernama Batik Tanah Liek Citra berada di Jorong Teluk Sikai, Nagari Sungai Duo, Kecamatan Sitiung. Industri Batik Tanah Liek Citra dikelola oleh seorang ibu rumah tangga yang bernama Eni Mulyatni. Industri batik tersebut didirikan oleh Eni Mulyatni pada tahun 1997 setelah mengikuti kegiatan belajar membatik dalam program pemberdayaan masyarakat desa di Jojga dan Solo selama enam bulan dan saat ini telah berusia 23 tahun, pada tahun 2020. Pembuatan batik pada industri ini menggunakan pewarna yang cukup beragam seperti warna kuning, coklat, merah, hitam, dan hijau yang semuanya menggunakan bahan tanah liek (liat) Noli (2020) dan proses produksi pada pembuatan batik dikerjakan oleh 30 orang perajin yang semuanya berprofesi sebagai ibu rumah tangga.

Industri Batik Tanah Liek di Sumatra Barat berdasarkan perkembangannya banyak mengalami berbagai kesulitan. Kesulitan tersebut di antaranya:

1. Tidak begitu termasyhurnya kain Batik Tanah Liek sebagai kain nusantara layaknya kain Songket Sumatra Barat (Rose, 2019).

2. Pemilik Industri Batik Tanah Liek Citra mengalami kesulitan dalam membeli bahan baku dan alat membatik yang berada di luar wilayah Pulau Sumatra.

3. Para perajin batik yang berprofesi sebagai ibu rumah tangga, mengalami kesulitan dalam membuat motif pada kain batik dalam proses produksi.

4. Terhambatnya pembuatan motif pada proses produksi menyebabkan kain Batik Tanah Liek Citra dalam penyelesaiannya memerlukan waktu yang cukup lama.

5. Rendahnya daya beli masyarakat Minangkabau yang tidak lagi menggunakan pakaian dan selendang Batik Tanah Liek Citra sebagai pakaian adat.

Industri Batik Tanah Liek Citra di Dharmasraya merupakan sebuah industri kecil rumahan. Menurut Rhodant dalam Pranoto (2008) mengatakan bahwa industri kecil adalah usaha produktif, terutama dalam bidang produksi barang atau jasa-jasa 
misalnya transportasi atau jasa. Menurut Tambunan (1999), industri kecil adalah kegiatan industri yang dapat diartikan sebagai usaha produktif di luar usaha pertanian, baik itu merupakan mata pencaharian utama maupun sampingan. Sedangkan menurut Nurhayati, et al. (2012) mengatakan bahwa industri kecil adalah kelompok usaha yang mampu menyerap banyak tenaga kerja dan menjadi sumber pendapatan masyarakat.

Industri Batik Tanah Liek Citra dalam pengelolaannya menggunakan bahan baku, alat membatik, waktu, dan tenaga manusia sebagai sumber daya yang diatur sedemikian rupa untuk menghasilkan dasar kain berupa pakaian, dan selendang batik sebagai produk pada manajemen produksi. Menurut Jazuli (2014) manajemen dalam bahasa Inggris adalah management berasal dari kata to manage, artinya mengatur, mengelola, mengendalikan sesuatu. Sedangkan menurut Follet dalam Wijayanti (2008) mengartikan manajemen sebagai seni dalam menyelesaikan pekerjaan melalui orang lain. Sedangkan menurut Gulick dalam Wijayanti (2008) mendefinisikan manajemen sebagai suatu bidang ilmu pengetahuan (science) yang berusaha secara sistematis untuk memahami mengapa dan bagaimana manusia bekerja bersama-sama untuk mencapai tujuan dan membuat sistem ini lebih bermanfaat bagi kemanusiaan, dan Wibowo (2013), manajemen suatu proses menggunakan sumber daya organisasi untuk mencapai tujuan organisasi melalui fungsi manajemen: planning, decision making, organizing, leading, dan controlling. Sedangkan manajemen produksi menurut Assauri (2004) adalah kegiatan untuk mengatur dan mengoordinasikan penggunaan sumber-sumber daya yang merupakan sumber daya manusia, sumber daya alat, dan sumber daya dana serta bahan, secara efektif dan efisien untuk menciptakan dan menambah kegunaan (utility) suatu barang atau jasa.

Menurut Suyadi (2001) mengatakan manajemen produksi adalah perencanaan, pelaksanaan, dan pengawasan dari urutan berbagai kegiatan untuk membuat barang yang berasal dari bahan baku dan bahan penolong lain. Menurut Assauri (2004) produksi adalah semua kegiatan dalam menciptakan dan menambah kegunaan suatu barang atau jasa. Faktor ketiga adalah tenaga kerja. Menurut Aziz (2008) mengatakan istilah produksi sering digunakan dalam term membuat sesuatu. Secara khusus, produksi adalah kegiatan untuk menciptakan atau menambah suatu barang atau jasa. Dalam istilah yang lebih luas dan lebih fundamental, produksi dapat diartikan sebagai berikut: pengubahan bahan-bahan dari sumber-sumber menjadi hasil yang diinginkan oleh konsumen. Hasil itu dapat berupa barang atau jasa dan menurut Suprayitno (2008) dalam ilmu ekonomi, pengertian produksi adalah kegiatan menghasilkan barang maupun jasa atau kegiatan menambah nilai kegunaan atau manfaat suatu barang.

Pada sebuah manajemen industri, salah satu faktor produksi yang tidak kalah penting ialah peran pemimpin dalam mengelola industri atau yang dapat 
dikatakan sebagai intangible factor of production pada entrepreneurship-nya. Entrepreneurship adalah orang-orang yang memiliki jiwa wirausaha dan mengaplikasikan hakikat kewirausahaan dalam hidupnya. Menurut Rosyid (2009), entrepreneur merupakan faktor produksi yang justru paling menentukan di dalam perkembangan perekonomian masyarakat. Menurut Suryana (2006), entrepreneur adalah mereka yang melakukan usaha-usaha kreatif dan inovatif dengan jalan mengembangkan ide dan menjalankan sumber daya untuk menemukan peluang dan perbaikan hidup. Faktor-faktor yang memengaruhi enterpreneurship salah satunya ialah selera. Menurut Suryana (2006) selera adalah kemauan yang dilengkapi dengan kemampuan untuk mendapatkan sesuatu. Contohnya, seorang pemilik kios yang memiliki kemauan untuk berjualan kebutuhan sehari-hari, tetapi tidak memiliki kemampuan untuk mengembangkannya maka, kios yang dimilikinya tidak akan berkembang.

Manajemen produksi yang dikelola menggunakan metode atau cara pemberdayaan pada sumber daya manusia melalui ibu rumah tangga sebagai perajin atau tenaga kerja. Menurut Case \& Fair (2007) tenaga kerja merupakan elemen yang cukup penting dalam kegiatan operasi suatu perusahaan. Sedangkan menurut Schuler 1992 dalam Sutrisno (2009) manajemen sumber daya manusia merupakan pengakuan tentang pentingnya tenaga kerja organisasi sebagai sumber daya manusia yang sangat penting dalam memberi kontribusi bagi tujuan-tujuan organisasi, dan menggunakan beberapa fungsi dan kegiatan untuk memastikan bahwa sumber daya manusia tersebut digunakan secara efektif dan adil bagi kepentingan individu, organisasi, dan masyarakat, serta menurut Handoko (2011) mengatakan bahwa manajemen sumber daya manusia adalah penarikan, seleksi, pengembangan, pemeliharaan, dan penggunaan sumber daya manusia untuk mencapai tujuan-tujuan individu maupun organisasi.

Proses pemilihan tenaga kerja pada manajemen produksi dengan memilih ibu-ibu rumah tangga sebagai perajin batik secara tidak langsung telah memberdayakan mereka dari tidak memiliki kemampuan membatik menjadi perajin batik. Menurut Smith tahun 2000 dalam Wibowo (2013), memberdayakan orang berarti mendorong mereka menjadi lebih terlibat dalam keputusan dan aktivitas yang memengaruhi pekerjaan mereka. Adapun manfaat pemberdayaan bagi organisasi mampu meningkatkan kinerja organisasi dan individu yang dapat mengembangkan bakatnya secara penuh. Selain itu, pemberdayaan memerlukan pengertian dan sikap saling memercayai antara atasan (manajer) dan bawahan (perajin).

Berdasarkan penjelasan sebelumnya dapat dikatakan bahwa manajemen produksi dalam sebuah industri memiliki peran yang sangat penting karena dapat menggambarkan metode atau cara serta teknik yang dilakukan untuk melewati berbagai hambatan atau kedala dalam menjalankan suatu usaha. Hal tersebut telah 
dibuktikan oleh Industri Batik Tanah Liek Citra dalam menjalankan industrinya hingga saat ini (2020) yang telah mencapai usia 23 tahun. Perjalanan Industri Batik Tanah Liek Citra yang cukup lama tersebut patut untuk dijadikan contoh oleh pebisnis muda yang ingin mendirikan Industri Batik Tanah Liek lainnya dan atau mencoba mengembangkan Industri Batik Tanah Liek sebagai produk handmade atau kerajinan, selain dari pakaian dan selendang. Berdasarkan pernyataan tersebut, maka penulis tertarik untuk mengetahui bagaimana proses manajemen Industri Batik Tanah Liek Citra di Kabupaten Dharmasraya.

\section{METODE PENELITIAN}

Pada penelitian ini penulis menggunakan metode penelitian kualitatif. Menurut Moleong (2016), penelitian kualitatif adalah penelitian yang bermaksud untuk memahami fenomena tentang apa yang dialami oleh subjek penelitian misalnya perilaku, persepsi, motivasi, tindakan, dan lain-lain secara holistik dan dengan cara deskripsi dalam bentuk kata-kata dan bahasa, pada suatu konteks khusus yang alamiah dan dengan memanfaatkan berbagai metode alamiah. Selanjutnya, teknik pengumpulan data dalam penelitian ini menggunakan pengamatan dan wawancara mendalam.

\section{Teknik Pengumpulan Data}

a. Data Primer

Data primer adalah sumber data penelitian yang diperoleh secara langsung. Data tersebut adalah sebagai berikut:

\section{1) Observasi}

Menurut Arikunto (2006) observasi adalah mengumpulkan data atau keterangan yang harus dijalankan dengan melakukan usaha-usaha pengamatan secara langsung ke tempat yang akan diselidiki. Observasi dilakukan dengan mengamati perilaku dan aktivitas para perajin di lokasi penelitian. Dalam pengamatan ini, penulis mencatat kegiatan yang dilakukan perajin selama membuat Batik Tanah Liek Citra.

\section{2) Wawancara}

Teknik wawancara menurut Sugiyono (2010), wawancara digunakan sebagai teknik pengumpulan data apabila penulis akan melaksanakan studi pendahuluan untuk menemukan permasalahan yang harus diteliti, dan juga penulis ingin mengetahui hal-hal dari responden yang lebih mendalam dan jumlah respondennya sedikit/kecil. Wawancara yang digunakan dalam penelitian ini adalah wawancara terstruktur dan terbuka. Wawancara dilakukan oleh penulis terhadap subjek penelitian yaitu Eni Mulyatni sebagai pemilik dan sekaligus manajer Batik Tanah Liek Citra. 


\section{b. Data Sekunder}

Data sekunder adalah data penelitian yang diperoleh melalui media perantara atau secara tidak langsung berupa buku, catatan, bukti yang telah ada, atau arsip, baik yang dipublikasikan maupun yang tidak dipublikasikan secara umum terkait Industri Batik Tanah Liek Citra.

\section{Variabel Penelitian}

Variabel dalam penelitian ini berisi subjek dan objek penelitian. Adapun subjek dan objek penelitian tersebut dapat dilihat pada tabel 1 .

Tabel 1. Subjek dan Objek Penelitian

\begin{tabular}{ccl}
\hline No. & \multicolumn{1}{c}{ Analisis Isi } & \multicolumn{1}{c}{ Variabel } \\
\hline 1. & Manajer Batik Tanah Liek & - Manajemen Produksi Batik Tanah Liek \\
& Citra & Citra. \\
& & - Perencanaan. \\
& & - Pelaksanaan. \\
& - Pengawasan. \\
\hline
\end{tabular}

\section{HASIL DAN PEMBAHASAN}

Manajemen yang digunakan dalam memproduksi Batik Tanah Liek Citra adalah pemberdayaan sumber daya manusia yang dijalankan sesuai dengan fungsi manajemen: perencanaan, pelaksanaan, dan pengawasan. Adapun proses manajemen produksi tersebut secara rinci sebagai berikut:

\section{Perencanaan}

Pemilik Industri Batik Tanah Liek Citra membuat beberapa perencanaan dalam memproduksi Tanah Liek Citra di antaranya:

a. Perencanaan Penerimaan Perajin Batik Tanah Liek Citra

Pada perencanaan penerimaan perajin batik, pemilik Industri Batik Tanah Liek Citra akan menerima calon perajin sesuai kriteria yang telah ditentukan. Adapun kriteria tersebut antara lain:

1) Mampu membatik pada bidang kain berukuran kurang lebih $60 \times 60 \mathrm{~cm}$.

2) Mampu melilin pada bidang kain.

3) Mampu memberi warna pada bidang kain.

4) Proses melilin rapi dan menembus bidang kain.

5) Mampu melorot kain yang telah dililin dan diberi warna.

6) Hasil batik menarik (sesuai dengan warna tanah liat).

Pada perencanaan tersebut pemilik Industri Batik Tanah Liek Citra tidak melakukan pembatasan usia untuk calon perajin batik, tidak melakukan batasan 
jenis kelamin atau calon perajin harus perempuan, dan tidak membuat kontrak kerja secara tertulis.

b. Perencanaan Program Belajar Membatik

Program belajar membatik direncanakan oleh pemilik Industri Batik Tanah Liek Citra selama periode penerimaan calon perajin baru dan sekaligus sebagai bentuk pengenalan Batik Tanah Liek Citra kepada masyarakat Dharmasraya, baik generasi muda maupun ibu-ibu rumah tangga yang ingin belajar membatik dan atau ingin menjadi perajin batik di tempat usahanya. Perencanaan tersebut dilakukan pemilik Industri Batik Tanah Liek Citra supaya masyarakat tertarik untuk menjadi perajin batik dan mau belajar membatik sehingga masyarakat kembali mengenakan kain Batik Tanah Liek Citra sebagai identitas Dharmasraya. Kegiatan tersebut dilakukan pemilik Industri untuk menghidupkan usahanya dan sekaligus sebagai bentuk pelestarian budaya membatik di Dharmasraya agar tidak hilang dan terlupakan.

c. Perencanaan Alat dan Bahan Produksi Batik Tanah Liek Citra

Setiap tahunnya pemilik Industri Batik Tanah Liek Citra melakukan perencanaan terkait alat dan bahan produksi yang diperlukan. Adapun perencanaan tersebut terkait dengan: a) pewarna batik, b) lilin, c) kain, d) kompor, e) meja membatik, f) canting, g) kuas, dan lain sebagainya. Perencanaan tersebut dilakukan untuk memperkirakan jumlah kain Batik Tanah Liek Citra yang mampu diproduksi dengan banyaknya tenaga perajin yang dibutuhkan serta untuk mengantisipasi banyaknya pesanan yang melebihi kapasitas dalam memproduksi Batik Tanah Liek Citra.

d. Perencanaan pendapatan

Perencanaan ini dilakukan pemilik Industri Batik Tanah Liek Citra terhadap hasil membatik yang telah dikerjakan oleh para perajin Batik Tanah Liek Citra dan berdasarkan kategori tertentu karena pemilik menyadari bahwa sejak usahanya dirintis, telah menggunakan pemberdayaan sumber daya manusia. Adapun pendapatan yang diperoleh para perajin disesuaikan dengan kategori: a) banyaknya kain yang dipola, b) banyaknya kain yang dililin, dan c) banyaknya kain yang diwarna. Pemilik Industri dalam perencanaan tersebut telah membagi tanggung jawab atau beban kerja berdasarkan kategori yang telah ditentukan untuk para perajin sesuai dengan kemampuannya masing-masing agar memudahkan perajin dalam bekerja. Penentuan perencanaan tersebut tidak memaksa para perajin yang ingin mencoba bekerja pada kategori pekerjaan lain atau selain dari pekerjaan yang biasa dikerjakan. Selain itu, pemilik industri membebaskan para perajin dalam mengerjakan proses membatik, yaitu apakah akan dikerjakan di rumah para perajin masing-masing atau di tempat usaha. Pemilik industri merencanakan hal tersebut agar perajin tidak bosan dan tetap mampu menghasilkan jumlah Batik Tanah Liek Citra yang ditargetkan. 


\section{Pelaksanaan}

Pelaksanaan dalam memproduksi Batik Tanah Liek Citra dilakukan sesuai dengan perencanaan yang telah disusun. Dalam proses membatik, pemilik industri akan membagi tanggung jawab atau beban kerja kepada para perajin sesuai dengan bidang yang diminati dan yang memiliki kemampuan di bidang tersebut, baik dalam melilin, mewarna, maupun membuat pola, serta membagi alat dan bahan yang mereka butuhkan selama membatik. Setelah semua perajin menjalankan tanggung jawabnya atau telah menyelesaikan beban kerja maka, para perajin akan melorot kain batik secara bersama-sama pada tempat yang telah disediakan. Setelah melalui proses pelorotan dan kemudian penjemuran maka setiap perajin akan menyerahkan kain batik yang telah dikerjakan untuk diberikan kepada pemilik Industri Batik Tanah Liek Citra dan di saat itulah mereka mendapatkan pendapatan (gaji). Setelah semua kain batik terkumpul (baik yang sedang diproduksi maupun yang telah selesai diproduksi) maka, pemilik Industri Batik Tanah Liek Citra akan membuka penerimaan pesanan dan melakukan proses pemasaran. Pada proses pemasaran, pemilik industri melakukan transaksi secara online (WhatsApp) maupun fisik (toko).

\section{Pengawasan}

Pada proses memproduksi Batik Tanah Liek Citra, pengawasan dilakukan oleh pemilik industri untuk melihat hasil pekerjaan yang telah dilakukan oleh para perajin terkait: pewarnaan, proses melilin, proses pewarnaan, dan proses melorot kain. Di dalam proses pengawasan ini pemilik Industri Batik Tanah Liek Citra akan mencatat kekurangan dan kelebihan para perajin batik dalam memproduksi Batik Tanah Liek Citra. Melalui catatan tersebut para perajin akan mengetahui hal apa saja yang perlu diperbaiki untuk mendapatkan hasil Batik Tanah Liek Citra yang baik. Pada proses ini pula pemilik Industri Batik Tanah Liek Citra akan melihat jumlah pesanan Batik Tanah Liek Citra yang dipesan oleh pelanggan dan ketersediaan Batik Tanah Liek Citra yang telah tersedia. Catatan dalam proses pengawasan tersebut akan dibacakan oleh pemilik industri pada saat para perajin menyelesaikan proses membatik atau setelah mendapatkan gaji.

\section{KESIMPULAN}

Berdasarkan hasil penelitian dapat disimpulkan bahwa manajemen produksi pada Industri Batik Tanah Liek Citra di Kabupaten Dharmasraya menggunakan manajemen pemberdayaan sumber daya manusia sebagai tenaga kerja atau perajin batik melalui program belajar membatik oleh pemilik industri melalui fungsi manajemen: perencanaan, pelaksanaan, dan pengawasan. Manajemen produksi pada Industri Batik Tanah Liek Citra dalam keberlangsungannya telah berperan 
dalam melestarikan budaya membatik khas masyarakat Minangkabau di Kabupaten Dharmasraya, Provinsi Sumatra Barat.

\section{KEPUSTAKAAN}

Arikunto, S. (2006). Prosedur Penelitian: Suatu Pendekatan Praktik. Jakarta: Rineka Cipta.

Arssad, M.; Jupriani,; A, E. (2015). Studi Tentang Desain Motif dan Teknik Batik Tanah Liek di Sanggar Citra Monalisa Sawahan Padang. SERUPA: The Journal of Art Education, 3(2), 1-17.

Assauri, S. (2004). Manajemen Pemasaran. Jakarta: Rajawali.

Fair, C. \&. (2007). Prinsip-Prinsip Ekonomi Mikro (terjemahan Y. Andri Zaimur). Jakarta: Erlangga.

Handoko, T. H. (2011). Manajemen Personalia dan Sumber Daya Manusia. Yogyakarta: Penerbit BPFE.

Jazuli. (2014). Manajemen Seni Pertunjukan. Yogyakarta: Graha Ilmu.

Moleong, L. J. (2016). Metodologi Penelitian Kualitatif Edisi Revisi. Bandung: PT. Remaja Rosdakarya.

Nurhayati, N.; Musa, H.; Sapta, R. (2012). Kelayakan dan Strategi Pengembangan Industri Kecil Tahu di Kbupaten Kuningan Jawa Barat. Jurnal Fakultas Teknologi Pertanian Institut Pertanian Bogor.

Pranoto, S. (2008). Analisis Indeks Keberlanjutan Industri Kecil dan Menengah di Kabupaten Bogor. Fakultas Teknologi Pertanian, Institut Pertanian Bogor.

Rosyid, S. (2009). Pengantar Teori Ekonomi. Jakarta: Rajawali.

Suryana. (2006). Kewirausahaan Pedoman Praktis: Kiat dan Proses Menuju Sukses Edisi Tiga. Jakarta: Salemba.

Sutrisno, E. (2009). Manajemen Sumber Daya Manusia. Jakarta: Kencana.

Suyadi, P. (2001). Manajemen Operasi: Analisis dan Studi Khasus. Jakarta: Bumi Aksara.

Tambunan, T. (1999). Perkembangan Industri Skala Kecil di Indonesia. Jakarta: PT. Mutiara Sumber Widya.

Wibowo. (2013). Manajemen Kerja. Jakarta: PT Raja Grafindo Persada.

Wijayanti, I. D. S. (2008). Manajemen. Yogyakarta: Mitra Cendikia Press.

\section{Webtografi}

Noli, M. H. (2020). Batik Tanah Liek, Batik Khas Dharmasraya. Retrieved from CENDANA News website: https://www.cendananews.com/2018/09/batiktanah-liek-batik-khas-dharmasraya.html

Rose, R. V. (2019). SONGKET PANDAI SIKEK-Ratunya Kain Tenun Nusantara. Retrieved from Blog Online-ARTWORLD The Window of World Art website: https://artworld.indeksnews.com/songket-pandai-sikek-ratunyakain-tenun-nusantara/ 